\title{
First Report of Olive Anthracnose, Caused by Colletotrichum gloeosporioides, in Morocco
}

\author{
El Hassan Achbani ${ }^{1 *}$, Abdellatif Benbouazza', and Allal Douira ${ }^{2}$
}

1 Centre Régional de la Recherche Agronomique, Unité de Recherche en Protection des Plantes, Laboratoire de Phytobactériologie et de lutte biologique, Km 11, route Hadj Kaddour, 50100, Meknès, Morocco ; ${ }^{2}$ Faculté des Sciences, Université Ibn Tofail, Laboratoire Botanique, Biotechnologie et Protection des Plantes, Kénitra, Morocco.

Received: June 30, 2013 / Accepted: November 17, 2013

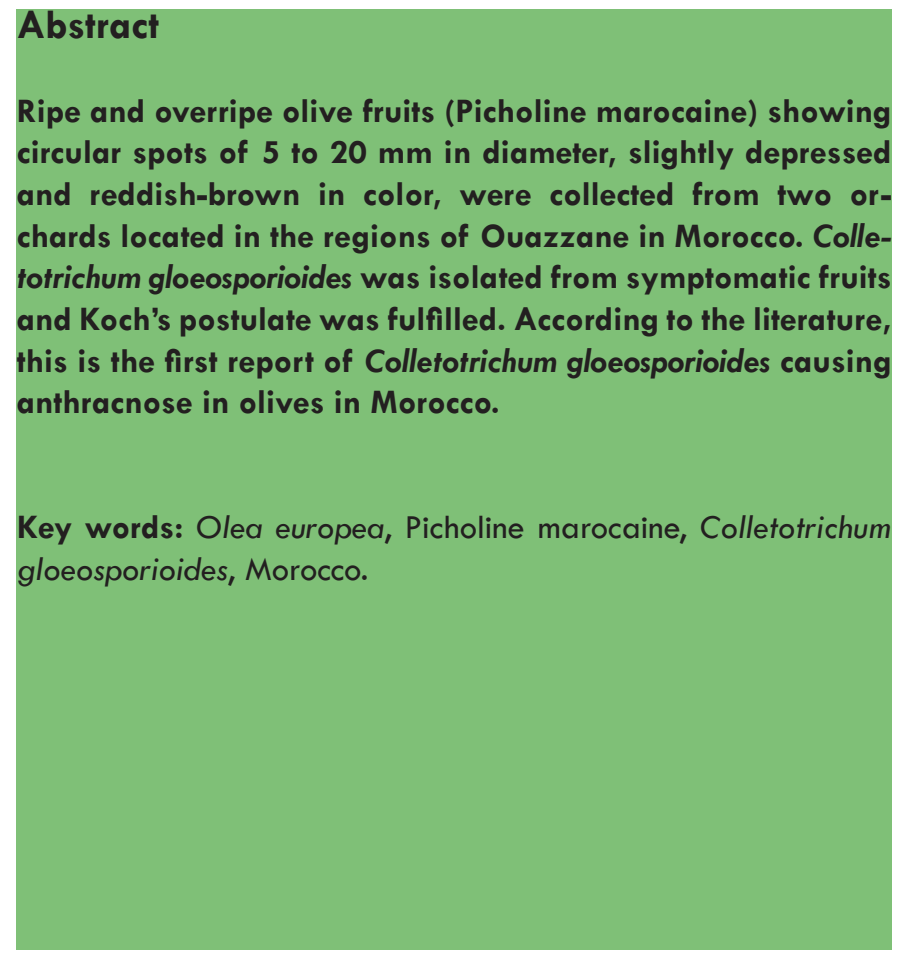

* Corresponding author: achbani105@gmail.com

\section{Introduction}

Olive (Olea europaea $\mathrm{L}$.) is subjected to be attacked with a variety of fungal pathogens, which affect its health, yield and its oil quality (Sanei et al., 2011). Anthracnose caused by Colletotrichum acutatum J.H. Simmonds and Colletotrichum gloeosporioides (Penz.) Penz. \& Sacc. (syn. Gloeosporium olivarum Alm.), widespread disease of olives in most olive-growing regions in the world, causing pre-and post-harvest problems (Sergeeva et al., 2008).

The disease was first reported in Portugal. Subsequently, it was reported in the Mediterranean countries such as Italy (Ciccarone, 1950; Agosteo et al., 2002; Moral et al., 2008), Spain (Martín et al., 2002), and Serbia and Montenegro (Latinovic and Vucinic, 2002), and Tunisia recently (Rhouma et al., 2010). The disease has also been reported in other countries such as Japan, Uruguay, Argentina, Brazil, South Africa, California, China, India, Australia and New Zealand (Margarita et al., 1986; Bompeix et al., 1988; Mugnai et al., 1993; Latinovic and Vucinic, 2002; Sergeeva et al., 2008; Duarte et al., 2010;).

Anthracnose symptom was, in most cases found on immature or mature olive fruits (between 50 and $80 \%$ )), while in some cases the leaves were also affected in two orchards ( 10 to $15 \%$ ) located in the region of Ouazzane (North-East of Morocco).
ATLOS Publishing, Lp
This is an Open Access article distributed under the terms of the Creative Commons Attribution License (http://creativecommons.org/licenses/by/3.0/), which permits unrestricted use, distribution, and reproduction in any medium, provided the original work is properly cited. 
The aim of the present work was to investigate the etiology of the anthracnose observed in December 2012 on fruit olives.

\section{Materials and Methods}

Samples of infected olive fruits were collected from two olive orchards in Ouazzane region (North-East of Morocco), placed in a cooler and taken to the laboratory. (refrigerated at $4{ }^{\circ} \mathrm{C}$ ). These olives showed a soft circular rot on their surface consisting of slightly depressed reddish brown spots. Such spots expanded to up to $20 \mathrm{~mm}$ in diameter and coalesced to form the characteristic circular sunken lesions (Fig. 1).

At the laboratory, portions $(5 \mathrm{~mm} 2)$ of the infected fruits, were removed at the point of progression of disease symptom; cut into small pieces and then soaked into in 10\% sodium hypochlorite $(\mathrm{NaOCl})$ for $3 \mathrm{~min}$, rinsed three times with sterile water, dropped after on sterile paper towels before plating them onto Potato Dextrose Agar (PDA) and incubated at $25^{\circ} \mathrm{C}$ for 10 days. Isolated colonies were, sub-cultured into fresh plates until pure cultures were obtained. Pure cultures obtained were identified by visual examinations and viewing under stereo mi-

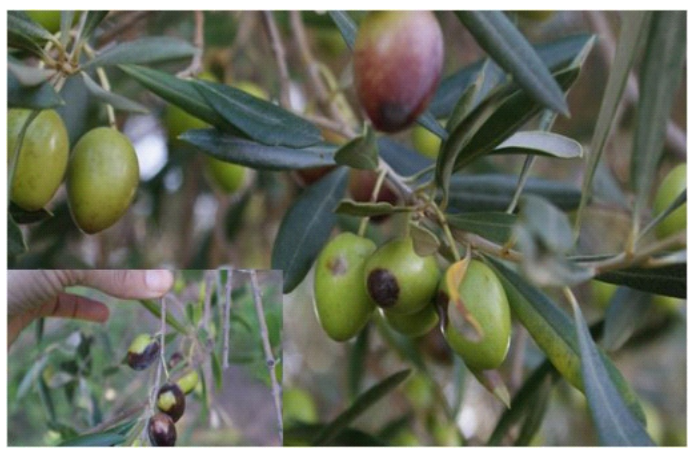

Figure 1. Olive Fruits showing brown spot symptoms of anthracnose.

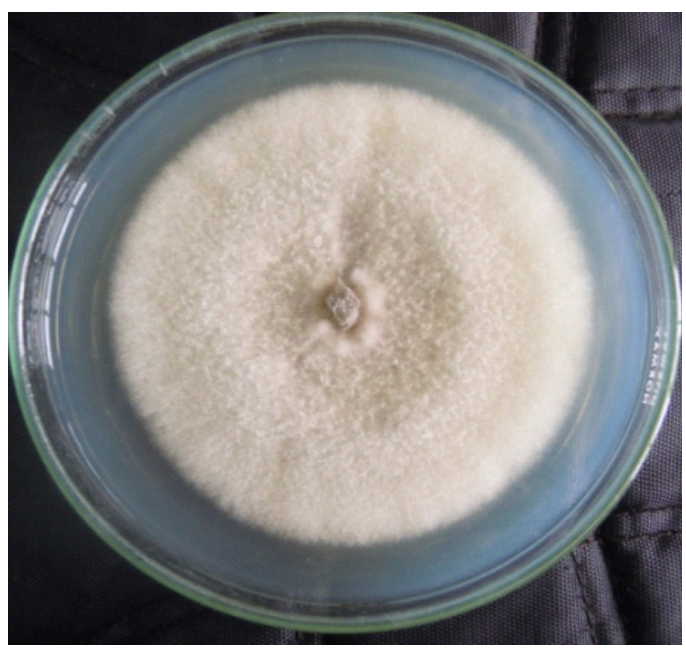

Figure 2. Macroscopic aspect of Colletotrichum gloeosporioides after ten days on PDA medium. croscope. They were then described and classified based on conidia and colony morphology as described by Barnett et Hunter Barry (1999).

\section{Pathogenicity Tests}

\section{Preparation of Spore Suspension}

In order to verify the pathogenicity of the isolated pathogen, ten olives (cv. Picholine marocaine) were surface-sterilized as above and the disinfected fruits were, then rinsed in three changes of sterile distilled water and air before inoculation.

Suspension of conidia was prepared by suspending mycelia scraped from 10 days old cultures of pathogens fungi in PDA. The resulting suspension was filtered through 2-layer cheesecloth. The concentration of spore suspension was adjusted to 106 conidia.milliliter-1 using haemacytometer.

\section{Inoculations}

The fruits were each, pierced with sterilized needle in one place; each fruit was injected with $25 \mu$ l of spore suspension of pathogen, then sealed in moist plastic bags, and incubated for 5 days in a moist chamber. Control fruits were, inoculated with sterile distilled water. Typical anthracnose symptoms were evaluated after 5 days (100\%).

Re-isolation of isolated fungal pathogens The causative organism in the diseased parts was re-isolated on potato dextrose agar as described in isolation of pathogen. The characters of the re-isolated pathogens were compared with their original isolates.

\section{Results and Discussion}

Obtained isolates on PDA from the affected fruit of olive trees, consistently produced one type of colonies. The cultures contained dense, white mycelium with a few orange conidial masses near the inoculum point (Fig. 2), simple conidiophores with an hyaline ovoid conidia, conidia size is 9-16.65 $\mu \mathrm{m}$ in lengh $\times 3$,33- $5 \mu \mathrm{m}$ in width (Fig. 3). The waxy acervuli (Fig. 4),

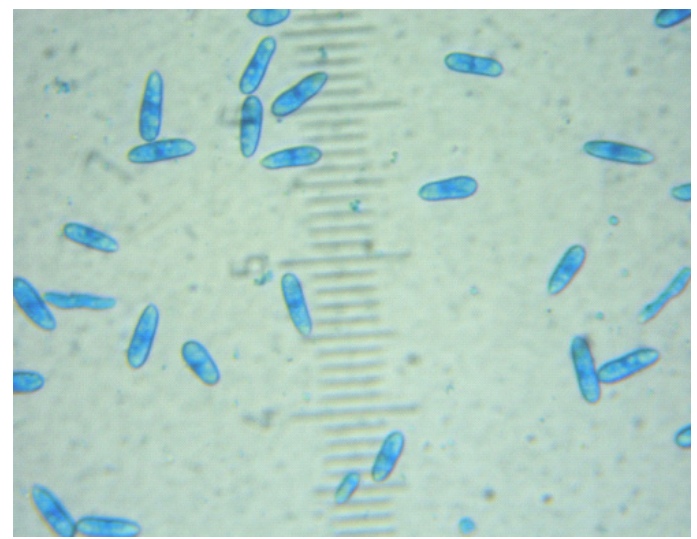

Figure 3. Colletotrichum gloeosporioides spores colored with cotton blue $\times 400$. 

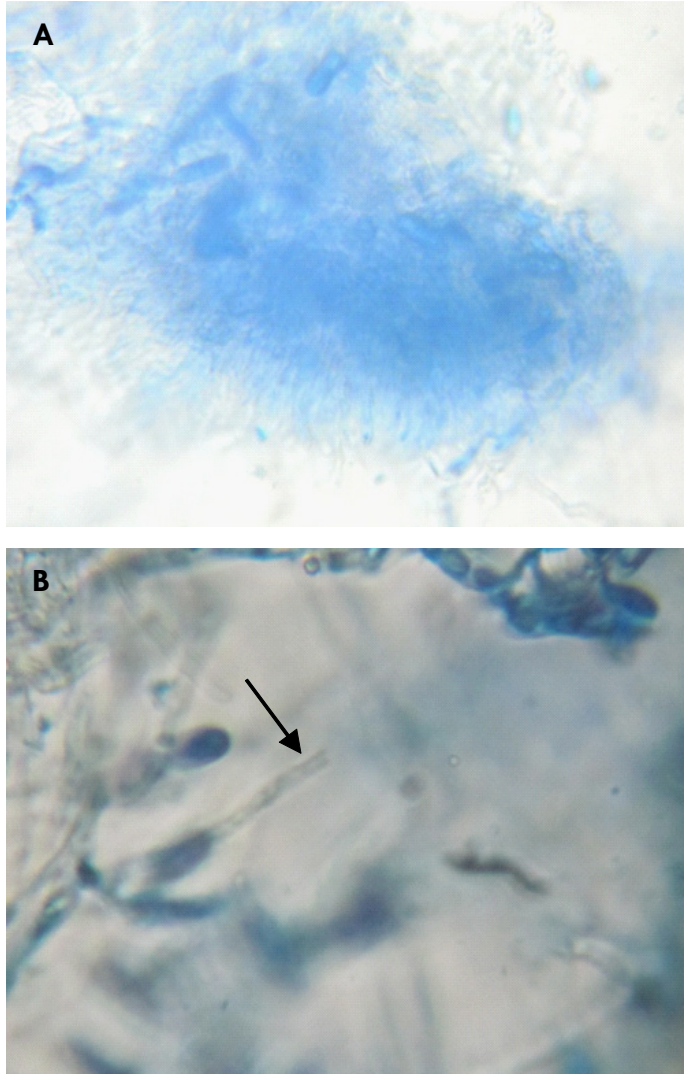

Figure 4. Colletotrichum gloeosporioides acervuli (A) with setae $(B)$ colored with cotton blue $\times 400$.

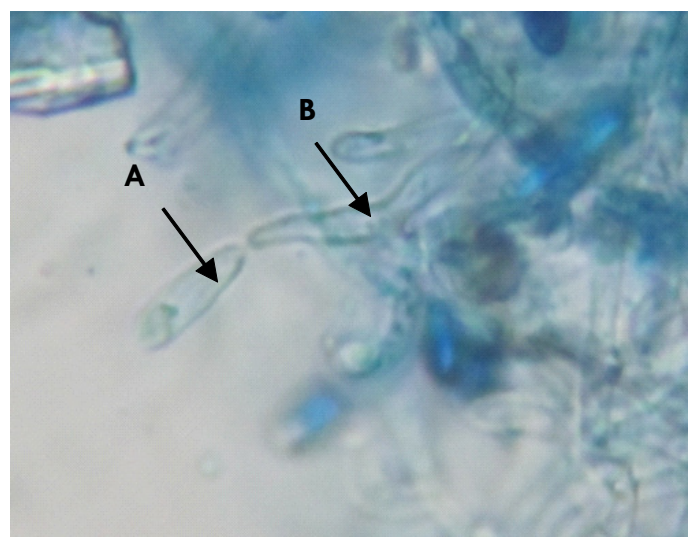

Figure 5. Colletotrichum gloeosporioides conidia (A) with a short erect conidiophore (B) colored with cotton blue $\times 400$.

typically with setae, and simple, short, erect conidiophores (Fig. 5). According to these characters and to Barnett key, this species could be Colletotrichum gloeosporioides. The colonization process of olive fruits by Colletotrichum such as spores adhesion and germination on cuticle to form an appressoria (Gomes et al., 2012). C. gloeosporioides usually attacks ripe or overripe fruits, and only rarely the leaves, peduncles and shoots. On the fruits, the disease causes soft circular rotted spots, on which slimy orange-colored masses of spores are produced under high hu-

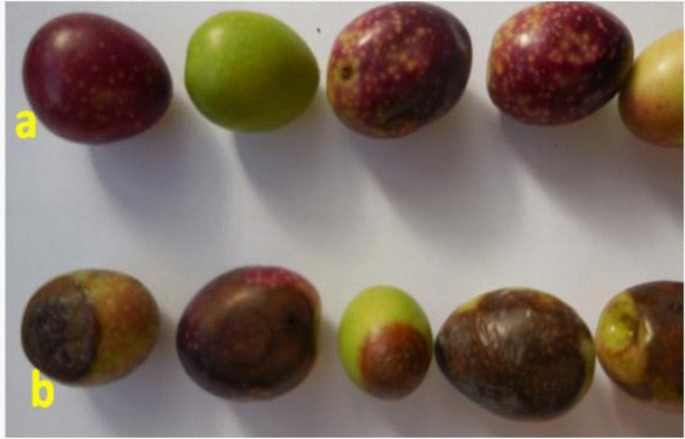

Figure 6. Typical anthracnose symptoms were observed after 5 days on the olive fruits after their inoculation with C. gloeosporioides (b) and No symptoms in olive fruits sprayed with sterile distilled water (a).

midity.

The pathogenicity of C. gloeosporioides was confirmed by artificial inoculation using a spore suspension (106 conidia.milliliter-1). Symptoms began to appear after 5 days of inoculation (Fig. 6). C. gloeosporioides was re-isolated from these lesions fulfilling Koch's postulate. No symptoms were produced in olive fruit sprayed with sterile distilled water.

Although C. gloeosporioides was reported on many hosts in different countries of the world (Farr et Rossman, 2011), to our knowledge, this is the first report of C. gloeosporioides affecting particularly the olive fruit in Morocco.

Anthracnose caused by C. gloeosporioides is one of the most important fungal foliar diseases affecting olive trees and the major disease of olive fruits. Fruit rot and mummification are the most important disease symptoms which result in high acidity and a reduced organoleptic quality of olive oil.

Besides C. gloeosporioides, C. acutatum also sporadically causes olive anthracnose. The co-occurrence of these two fungi was reported in Spain on a very limited scale (Martín and García-Figueres, 1999). However, Talhinhas et al. (2005) stated that these two species were not seen together on the same plant. With molecular and phenotypic assays, these authors reported that the occurrence of $\mathrm{C}$. acutatum in Portuguese olive orchards was higher $(>97 \%)$ than C. gloeosporioides (<3\%). Colletotrichum acutatum produced orange to pink coloured colonies with whitish aerial mycelium on potato dextrose agar (PDA). Colletotrichum gloeosporioides produced grey colonies with whitish aerial mycelium on PDA (Sergeeva et al., 2008). Also, conidia of C. gloeosporioides isolates are cylindrical with obtuse ends and measured 13 to $24 \mu \mathrm{m}$ in length, whereas conidia of the $\mathrm{C}$. acutatum isolates are elliptical-fusiform, tapered and acute at both ends, and measured 13 to $20 \mu \mathrm{m}$ in length (Gunnell et al., 1992).

In olive-growing areas where anthracnose was endemic, disease control was primarily based on early harvesting in order to escape secondary infections of the very susceptible mature and overripe drupes. Direct control measures involving regular fungicide sprays were used both to prevent defoliation and to avoid yield losses. Aerial spraying of Bordeaux mixture or copper oxychloride had been successfully attempted; two or three 
preventive treatments from late September to the end of December proved effective against fruit anthracnose (Martelli and Piglionica, 1961; Graniti et al., 1993; Pennisi et al., 1993).

\section{References}

Agosteo GE, G Magnano di San Lio, SO Cacciola, and S Frisullo (2002) Characterisation of the causal agent of olive anthracnose in Southern Italy. Acta Horticulturae 586: 713-716.

Barnett HL, and Hunter Barry B (1999) Illustrated Genera of Imperfect Fungi (4th Edition). The American Phytopathological Society St. Paul, Minnesota, 218pp.

Bompeix G, EVR Julio, and DH Phillips (1988) Glomerella cingulata (Stoneman) Spaulding et von Schrenk. In: Smith IM, J Dunez, RA Lelliott, DH Phillips, Archer S.A.(eds) European Handbook of Plant Diseases. Blackwell Scientific Publications, Oxford, UK, pp. 325-327

Ciccarone A (1950) Considerazioni biologiche e sistematiche sull'agente della "lebbra" delle olive, recentemente osservata nel Leccese. Bollettino della Regia Stazione di Patologia Vegetale di Roma, S. III 5: 143-165.

De Almeida MJV (1899) La gaffa des olives en Portugal. Bulletin de la Société Mycologique de France 15: 90-94.

Duarte HSS, PGC Cabral, OL Pereira, L Zambolim, ED Gonçalves, J Vieira Neto, EM Zambolim, and V Sergeeva (2010) First report of anthracnose and fruit mummification of olive fruit (Olea europaea) caused by Colletotrichum acutatum in Brazil. New Disease Reports 20:37.

Farr DF, AY Rossman (2011) Fungal Databases. Systematic Mycology and Microbiology Laboratory, ARS, USDA. Retrieved March 15, 2011 from http://nt.ars-grin.gov/fungaldatabases/.

Gomes S, Bacelar E, Martins-Lopes P, Carvalho T, and Guedes-Pinto H (2012). Infection Process of Olive Fruits by Colletotrichum acutatum and the Protective Role of the Cuticle and Epidermis. Journal of Agricultural Science, 4 (1): 101-110.

Gunnell PS, and Gubler, WD (1992) Taxonomy and morphology of Colletotrichum species pathogenic to strawberry. Mycologia, 84:157-165.

Graniti A, S Frisullo, AM Pennisi, and G Magnano di San Lio (1993) Infections of Glomerella cingulata on olive in Italy. Bulletin OEPP/ EPPO Bulletin 23: 457-465.

Latinovic J, and Z Vucinic (2002) Cultural characteristics, pathogenicity, and host range of Colletotrichum gloeosporioides isolated from olive plants in Montenegro. Acta Horticulturae 586: 753-755.
Margarita L, A Porta-Puglia, and A Quacquarelli (1986) Colletotrichum acutatum, nuovo patogeno dell'olivo in Cina e confronto con l'agente della "lebbra" dell'olivo. Annali dell'Istituto Sperimentale per la Patologia Vegetale 11: 125-133.

Martelli GP, V Piglionica (1961) Tre anni di lotta contro la lebbra delle olive in Puglia. Phytopathologia Mediterranea 3: 101-112.

Martín M, F García-Figueres and A Trapero (2002) Iniciadores específicos para detectar las especies de Colletotrichum causantes de la antracnosis de los olivos. Boletin de Sanidad Vegetal, Plagas 28: 43-50.

Martín MP, and F García-Figueres (1999) Colletotrichum acutatum and C. gloeosporioides cause anthracnose on olives. European Journal of Plant Pathology 105: 733-741.

Moral J, K Bouhmidi, and A Trapero (2008) Influence of fruit maturity, cultivar susceptibility, and inoculation method on infection of olive fruit by Colletotrichum acutatum. Plant Disease 92: 1421-1426.

Mugnai L, G Surico, and A Ragazzi (1993) Glomerella cingulata on olive in India: morphological and pathological notes. Bulletin OEPP/ EPPO Bulletin 23: 449-455.

Pennisi AM, GE Agosteo, and S Grasso (1993) Chemical control of the olive rot caused by Glomerella cingulata. Bulletin OEPP/EPPO Bulletin 23: 467-472.

Rhouma A, MA Triki, and M Msallem (2010) First report of olive anthracnose caused by Colletotrichum gloeosporioides in Tunisia. Phytopathologia Mediterranea 49: 95-98.

Ritchie BJ and PF Cannon (2003) Colletotrichum In: Plant Health Diagnostics, Introduction to Fungi. CABI Bioscience 2003, CAB International, Wallingford, UK, 123 pp.

Sanei SJ, SE Razavi, and K Ghanbarnia (2011). Fungi on Plants and Plant Products in Iran. Peik-e-Reihan Publication, Gorgan, 680 pp. In Press.

Sergeeva V, NG Nair, and R Spooner-Hart (2008). Evidence of early flower infection in olives (Olea europaea) by Colletotrichum acutatum and C. gloeosporioides causing anthracnose disease. Australasian Plant Disease Notes 3: 81-82.

Sergeeva V., NairA N. G., and Spooner-Hart R., 2008. First report of Colletotrichum acutatum and $C$. gloeosporioides causing leaf spots of olives (Olea europaea) in Australia. Australasian Plant Disease Notes, 3 : 143-144.

Talhinhas P, S Sreenivasaprasad, J Neves-Martin, and H Oliveira (2005) Molecular and phenotypic analyses reveal the association of diverse Colletotrichum acutatum groups and a low level of $C$. gloeosporioides with olive anthracnose. Applied and Environmental Microbiology 71: 2987-2998. 